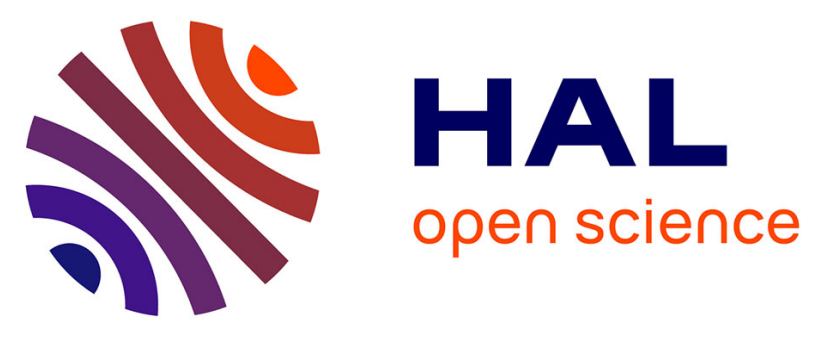

\title{
A Bioinspired Nickel(bis-dithiolene) Complex as a Homogeneous Catalyst for Carbon Dioxide Electroreduction
}

Thibault Fogeron, Tanya K Todorova, Jean-Philippe Porcher, Maria Gomez-Mingot, Lise-Marie Chamoreau, Caroline Mellot-Draznieks, Yun Li, Marc Fontecave

\section{To cite this version:}

Thibault Fogeron, Tanya K Todorova, Jean-Philippe Porcher, Maria Gomez-Mingot, Lise-Marie Chamoreau, et al.. A Bioinspired Nickel(bis-dithiolene) Complex as a Homogeneous Catalyst for Carbon Dioxide Electroreduction. ACS Catalysis, 2018, 8 (3), pp.2030-2038. 10.1021/acscatal.7b03383 . hal-01830033

\section{HAL Id: hal-01830033 \\ https://hal.sorbonne-universite.fr/hal-01830033}

Submitted on 4 Jul 2018

HAL is a multi-disciplinary open access archive for the deposit and dissemination of scientific research documents, whether they are published or not. The documents may come from teaching and research institutions in France or abroad, or from public or private research centers.
L'archive ouverte pluridisciplinaire HAL, est destinée au dépôt et à la diffusion de documents scientifiques de niveau recherche, publiés ou non, émanant des établissements d'enseignement et de recherche français ou étrangers, des laboratoires publics ou privés. 


\section{A Bioinspired Nickel(bis-dithiolene) Complex as a Homogeneous Catalyst for Carbon Dioxide Electroreduction}

Thibault Fogeron, ${ }^{[a]}$ Tanya K. Todorova, ${ }^{[a]}$ Jean-Philippe Porcher, ${ }^{[a]}$ Maria GomezMingot, ${ }^{[a]}$ Lise-Marie Chamoreau, ${ }^{[b]}$ Caroline Mellot-Draznieks, ${ }^{[a]}$ Yun $\mathrm{Li}^{*[a]}$ and Marc Fontecave ${ }^{\star[a]}$

[a] Laboratoire de Chimie des Processus Biologiques, UMR 8229 CNRS, Collège de France, Université Paris 6, 11 Place Marcelin Berthelot, 75231 Paris Cedex 05, France.

[b] Sorbonne Universités, UPMC Université Paris 6, Institut Parisien de Chimie Moléculaire, UMR 8232 CNRS, 4 place Jussieu, 75252 Paris Cedex 5, France.

\section{ABSTRACT}

Inspired by the metal active sites of formate dehydrogenase and CO-dehydrogenase, a nickel complex containing a $\mathrm{NiS}_{4}$ motif with two dithiolene ligands mimicking molybdopterin has been prepared and structurally characterized. During electroreduction, it converts into a good catalyst for the reduction of $\mathrm{CO}_{2}$ into formate as the major product, together with minor amounts of carbon monoxide and hydrogen, with reasonable overpotential requirement, good faradaic yield and notable stability. Catalysis operates on a mercury electrode and dramatically less on a carbon electrode, as observed in the case of $[\mathrm{Ni} \text { (cyclam) }]^{2+}$ complexes. DFT computations indicate the key role of a $\mathrm{Ni}(\mathrm{III})$-hydride intermediate and provide insights into the different reaction pathways leading to $\mathrm{HCOOH}, \mathrm{CO}$ and $\mathrm{H}_{2}$. This study opens the route towards a new class of mononuclear sulfur-coordinated $\mathrm{Ni}$ catalysts for $\mathrm{CO}_{2}$ reduction, unexplored yet.

KEYWORDS: dithiolene ligands, homogeneous catalysis, $\mathrm{CO}_{2}$ reduction, Nickel, density functional calculations. 


\section{INTRODUCTION}

Carbon dioxide 2-electron reduction into the energy-rich products, such as carbon monoxide (CO) and formic acid ( $\mathrm{HCOOH})$, offers the opportunity to develop synthetic organic reactions using $\mathrm{CO}_{2}$ as a source of carbon, providing an alternative to fossil sources, as well as a way to store renewable energies into chemical energy durably. For such electrochemical processes, molecular catalysts have several substantial benefits. ${ }^{1,2}$ First, their activity (reaction rates and overpotentials) can be finely tuned via simple modifications of the electronic properties of the organic ligands. Second, they are in general quite selective. In particular competition with proton reduction can also be controlled synthetically. ${ }^{3}$ As a consequence, during the last 40 years a number of molecular complexes have been studied for their catalytic activity for $\mathrm{CO}_{2}$ electroreduction into $\mathrm{CO} / \mathrm{HCOOH} .{ }^{1,2}$ However, the best catalysts so far are based on expensive noble metals, such as rhenium, iridium, rhodium and ruthenium. ${ }^{4,5}$ There are exceptions, notably the Fe-porphyrin systems developed by Savéant, Costentin and Robert, ${ }^{6}$ but also some cobalt, iron and manganese complexes. ${ }^{1,2,7}$

Surprisingly there is a very limited contribution of $\mathrm{Ni}$ complexes so far, the prototype being $\mathrm{Ni}(\mathrm{cyclam})^{2+}$, a catalyst with excellent activity in aqueous solutions and highly selective for $\mathrm{CO}$ production, developed in the 80's by Sauvage and collaborators and revisited by several groups recently. ${ }^{8-14}$ Examples of Ni-based catalysts are: (i) $\mathrm{Ni}$ polypyridine systems, such as $\left[\mathrm{Ni}(\text { bipy })_{3}\right]^{2+},\left[\mathrm{Ni}(\text { phen })_{3}\right]^{2+}$, and $\left.\mathrm{Ni}(\text { terpy })_{2}\right]^{2+}$ (bipy, phen, terpy = bipyridine, phenanthroline, and terpyridine respectively) which catalyze the selective conversion of $\mathrm{CO}_{2}$ into $\mathrm{CO}$, albeit with large overpotential requirements and low Faradaic yields; $;^{1,15}$ (ii) $\mathrm{Ni}$ complexes supported by N-heterocyclic carbeneamine ligands and displaying high selectivity and activity for the electrocatalytic and photocatalytic conversion of $\mathrm{CO}_{2}$ to $\mathrm{CO} ;{ }^{16}$ (iii) very recently, a $\mathrm{Ni}$ complex bearing a $\mathrm{S}_{2} \mathrm{~N}_{2}$-type tetradentate ligand which was found to selectively catalyze $\mathrm{CO}_{2}$ reduction to $\mathrm{CO}$ in a visible-light-driven photocatalytic system. ${ }^{17}$

In the quest for new Ni-based molecular catalysts for $\mathrm{CO}_{2}$ electro-reduction, we were intrigued by the possibility to explore $\mathrm{Ni}$ complexes supported by bioinspired ligands, with a specific interest for those ligands providing a sulfur-rich environment to the metal ion. Several lines of evidence point to the importance of sulfur ligation in active sites of metalloenzymes catalyzing $\mathrm{CO}_{2}$ reduction. First, in one class of $\mathrm{CO}$ dehydrogenases, a redox active $\mathrm{Ni}$ center is ligated by three $\mathrm{S}$ atoms, two provided 
by sulfide from an iron-sulfur cluster and one by a cysteine residue, and catalyzes the reduction of $\mathrm{CO}_{2}$ to $\mathrm{CO}^{18}$ In a second class of Mo/Cu CO-dehydrogenase ${ }^{19}$ as well as in formate dehydrogenase, which catalyzes the reduction of $\mathrm{CO}_{2}$ into formate, the metal center is composed of molybdenum (or tungsten) ions chelated by one or two dithiolene ligands provided by molybdopterin. ${ }^{20,21}$ The objective of this work is to investigate bis-dithiolene complexes of nickel as catalysts for $\mathrm{CO}_{2}$ electroreduction. A few $\mathrm{Ni}$ (bis-dithiolene) complexes, using benzene-1,2-dithiolate, ${ }^{22}$ diaryl-dithiolene ${ }^{23}$ or 5,6-dicyanopyrazine-2,3-dithiolate ${ }^{24}$ as ligands, have been recently shown to catalyze proton electroreduction into $\mathrm{H}_{2}$. However, to the best of our knowledge, there is no report of such complexes as catalysts for $\mathrm{CO}_{2}$ reduction.

Here, we report the first $\mathrm{Ni}$ (bis-dithiolene) complex, and at the same time the first $\mathrm{Ni}$ complex having a $\mathrm{NiS}_{4}$ coordination, that can perform catalytic reduction of $\mathrm{CO}_{2}$. It contains a quinoxaline-pyran-fused dithiolene ligand, $\mathbf{q p d t}^{2-}$ (Figure 1) that mimics the natural molybdopterin cofactor (MPT, Figure 1) present in the active site of formate dehydrogenase and CO-dehydrogenase. This bioinspired ligand has been previously used to obtain the $\left(\mathrm{Bu}_{4} \mathrm{~N}\right)_{2}\left[\mathrm{Mo}^{\mathrm{IV}} \mathrm{O}(\mathrm{qpdt})_{2}\right]$ and $\left(\mathrm{Et}_{4} \mathrm{~N}\right)_{2}\left[\mathrm{Co}^{\mathrm{III}}(\mathrm{qpdt})_{2}\right]_{2}$ complexes, which proved to be good catalysts for proton reduction. ${ }^{25,26}$
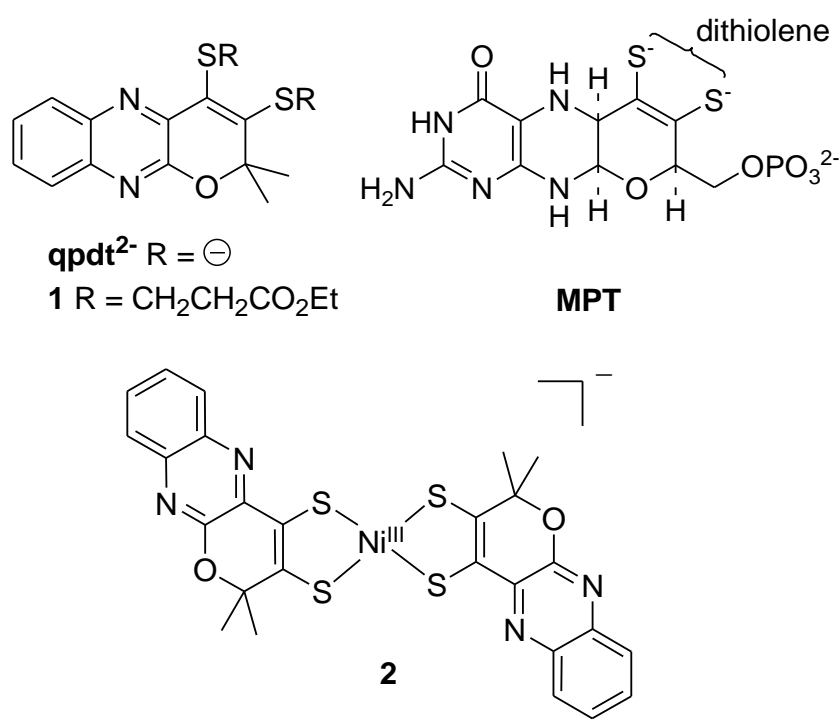

Figure 1. Structures of ligand $\mathrm{qpdt}^{2-}$ in its protected form 1, molybdopterin (MPT) and [Ni"l'(qpdt) $\left.]^{-}\right]^{-}(2)$.

The synthesis, structural characterization and electrochemical properties of the nickel complex $\left[\mathrm{Ni}^{\text {:ll }}(\mathrm{qpdt})_{2}\right]^{-}$are thus described. This complex allows catalytic electroreduction of $\mathrm{CO}_{2}$ into formate as the major product together with small amounts of $\mathrm{CO}$ and $\mathrm{H}_{2}$, with remarkable stability, good faradaic yield and reasonable 
overpotential requirements. Similar to $[\mathrm{Ni}(\mathrm{cyclam})]^{2+}$ complex, catalysis is greatly promoted by interactions between the complex and the surface of the $\mathrm{Hg}$ electrode. ${ }^{12}$ Density functional theory (DFT) computations were performed to explore possible reaction pathways for the $\mathrm{CO}_{2}$ reduction catalyzed by the $\left[\mathrm{Ni}(\mathrm{qpdt})_{2}\right]^{-}$catalyst and to explain how the mixture of products can be formed.

\section{RESULTS}

\section{Synthesis and characterization of the $\left[\mathrm{Ni}^{\mathrm{III}}(\mathrm{qpdt})_{2}\right]^{-}$complex}

Starting from the previously described protected dithiolene derivative $1,{ }^{25,27}$ complex 2 was synthesized (see Figure 1 for the structures of 1 and 2): compound 1 was treated with $t \mathrm{BuOK}$ under anaerobic conditions to generate the dithiolene ligand qpdt ${ }^{2-}$ in situ; then reaction with $\mathrm{Ni}\left(\mathrm{ClO}_{4}\right)_{2} \cdot 2 \mathrm{H}_{2} \mathrm{O}$ followed by cation exchange with $\mathrm{Ph}_{4} \mathrm{PCl}$ afforded the square-planar complex $\left.\left(\mathrm{Ph}_{4} \mathrm{P}\right)\left[\mathrm{Ni}^{\text {III }} \text { (qpdt) }\right)_{2}\right](2 \mathrm{a})$ in $52 \%$ yield. The redox active $\mathrm{Ph}_{4} \mathrm{P}^{+}$counter-cation is reducible at $-1.8 \mathrm{~V}$ vs. $\mathrm{Ag} / \mathrm{AgCl}$ (Figure S1) which is within the range of potentials for catalysis. Thus all $\mathrm{CO}_{2}$ electroreduction experiments were conducted with the same complex having $\mathrm{Bu}_{4} \mathrm{~N}^{+}$as the countercation, namely $\left(\mathrm{Bu}_{4} \mathrm{~N}\right)\left[\mathrm{Ni}^{\prime \prime \prime}(\mathrm{qpdt})_{2}\right](\mathbf{2 b})$. Both $\mathbf{2} \mathbf{a}$ and $\mathbf{2} \mathbf{b}$ are air-stable and can be purified by chromatography over silica gel. However only 2 a could be structurally characterized.

Single crystals suitable for $X$-ray diffraction were isolated for $\mathbf{2 a}$ by layering a $\mathrm{CH}_{2} \mathrm{Cl}_{2}$ solution of the complex with pentane. A summary of the crystal data collection and refinement parameters are listed in Table S1. Selected interatomic bond lengths and angles are given in Table S2. An ORTEP-like diagram of the anionic part of $\mathbf{2 a}$ is shown in Figure 2. Complex 2a crystallizes in the monoclinc system and the unit cell includes four mononuclear complexes and four $\mathrm{Ph}_{4} \mathrm{P}^{+}$ions. The $\mathrm{Ni}$ cation is tetracoordinated in a $S_{4}$ environment with a square planar geometry. The four sulfur atoms belong to two symmetric trans-oriented $\mathrm{qpdt}^{2-}$ ligands. The $\mathrm{Ni}-\mathrm{S}$ bond lengths $(2.1445(3)$ and $2.1536(3) \AA)$ are similar to those reported previously for $\mathrm{Ni}($ bisdithiolene) complexes. ${ }^{23}$

Complex 2a is soluble in common solvents $\left(\mathrm{CH}_{2} \mathrm{Cl}_{2}, \mathrm{THF}, \mathrm{CH}_{3} \mathrm{CN}\right.$, DMF). Its UVvisible spectrum in $\mathrm{CH}_{3} \mathrm{CN}$ (Figure S2) shows five absorption maxima at 975, 627, 
410, 392 and $314 \mathrm{~nm}$ with molar extinction coefficients $\varepsilon=18240,6400,37040$, 34400 and $30400 \mathrm{M}^{-1} \cdot \mathrm{cm}^{-1}$ respectively. $2 a$ is paramagnetic and thus, no NMR spectrum could be recorded. The negative-ion electrospray mass spectrum in acetonitrile solution exhibits one peak at $\mathrm{m} / \mathrm{z}=605.95\left(\left[\mathrm{Ni}(\mathrm{qpdt})_{2}\right]^{-}\right)$, which is consistent with the structure (Figure S3).

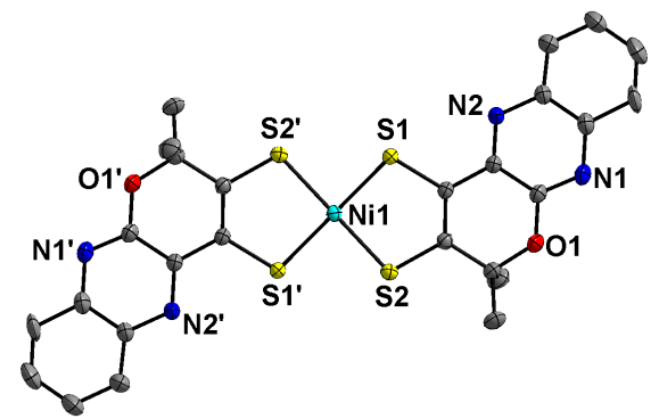

Figure 2. X-ray structure of $\left[\mathrm{Ni}^{\prime \prime \prime}(\mathrm{qpdt})_{2}\right]^{-}$(within 2a) at $50 \%$ probability. Hydrogen atoms are omitted for clarity.

The X-band EPR spectrum of $2 \mathbf{a}$ in dichloromethane at $6 \mathrm{~K}$ (Figure S4) exhibits a sharp EPR signal $(g=2.002)$, which is similar to the previously reported spectrum recorded for $\left(\mathrm{PPh}_{4}\right)\left[\mathrm{Ni}^{\prime \prime \prime}\left(\mathrm{S}_{2} \mathrm{C}_{2} \mathrm{R}_{2}\right)_{2}\right]$ complex $\left(\mathrm{R}=\mathrm{CO}_{2} \mathrm{Me}\right),{ }^{28}$ suggesting a ligand-centered radical. It is thus more appropriate to describe $\mathbf{2 a}$ as $\left(\mathrm{PPh}_{4}\right)\left[\mathrm{Ni}^{\prime \prime}\left(\mathrm{qpdt}^{2-}\right)\left(\mathrm{qpdt}^{-}\right)\right]$rather than $\left(\mathrm{PPh}_{4}\right)\left[\mathrm{Ni}^{\mathrm{II \prime}}\left(\mathrm{qpdt}^{2-}\right)_{2}\right]$.

Figure 3 shows the cyclic voltammograms (CVs) of $\mathbf{2} \mathbf{b}$ in dry acetonitrile on a glassy carbon electrode (GCE) (Figure $3 \mathrm{~A}$ ) and a mercury/gold amalgam electrode (Figure 3B). Under a $\mathrm{N}_{2}$ atmosphere, $2 \mathrm{~b}$ displays a reversible wave at $-0.39 \mathrm{~V}$ corresponding to the $\left[\mathrm{Ni}(\mathrm{qpdt})_{2}\right]^{-} /\left[\mathrm{Ni}(\mathrm{qpdt})_{2}\right]^{2-}$ couple and an irreversible wave at $2.08 \mathrm{~V}$ on a GCE (Figure $3 \mathrm{~A}$ ). The peak current at $-0.39 \mathrm{~V}$ displays a linear relation to the square root of the scan rate, proving a diffusion-controlled electrochemical process typical for molecular complexes (Figure S5). The CV obtained on the $\mathrm{Hg} / \mathrm{Au}$ electrode is essentially identical to the previous one, with the exception of the presence of a tiny additional feature at $-0.9 \mathrm{~V}$ (Figure 3B). This signal is likely reflecting the adsorption of the complex on the $\mathrm{Hg}$ electrode as reported for the case of $[\mathrm{Ni}(\text { cyclam })]^{2+}$ complexes. $^{8,10,12}$ 

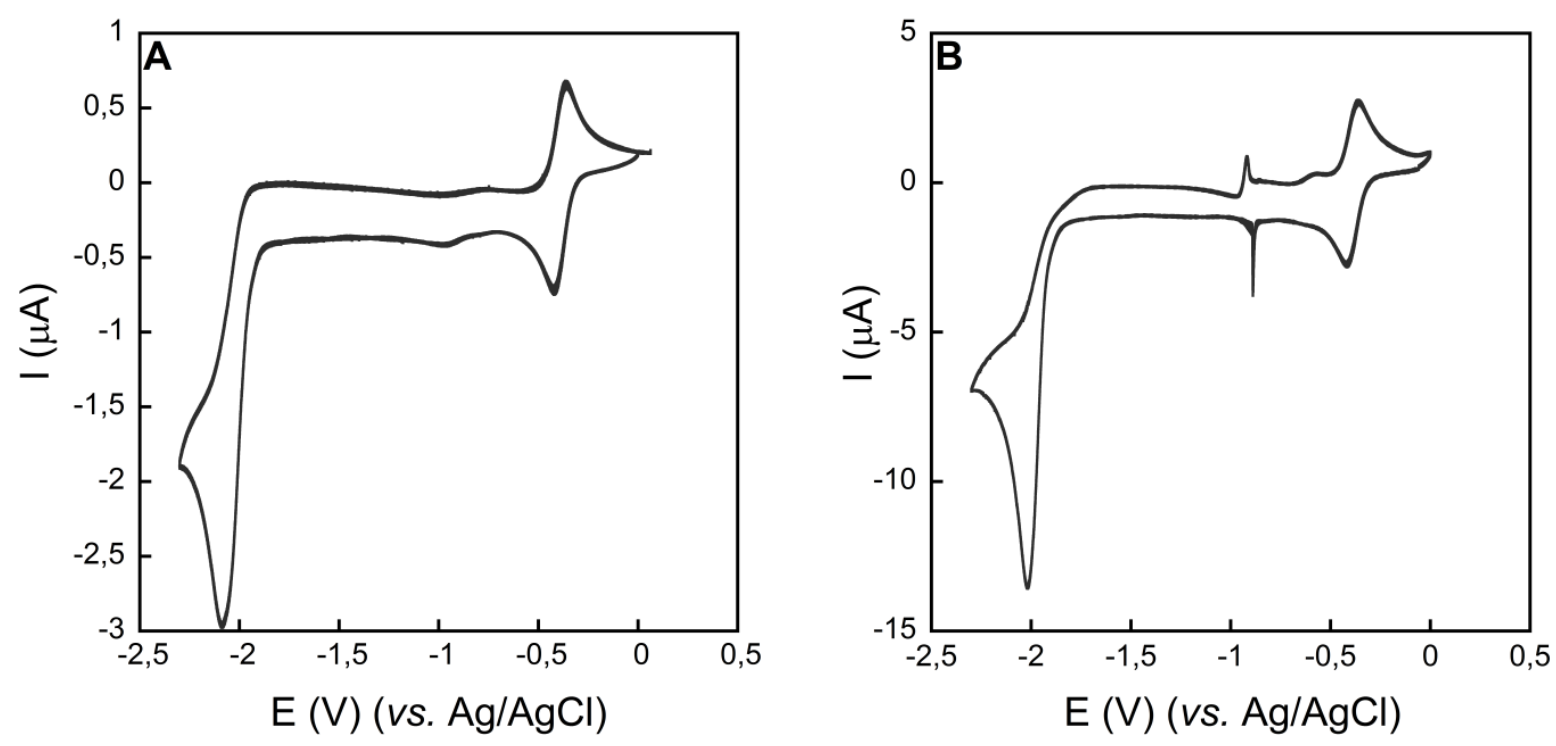

Figure 3. Cyclic voltammogram of $0.5 \mathrm{mM}$ complex $2 \mathbf{b}, 0.1 \mathrm{M}$ tetrabutylammonium perchlorate (TBAP) under $\mathrm{Ar}$ in dry acetonitrile $\left(\mathrm{CH}_{3} \mathrm{CN}\right)$ (A) on a $\mathrm{GCE}$ (glassy carbon electrode), (B) on a $\mathrm{Hg} / \mathrm{Au}$ amalgam electrode. Scan rate: $50 \mathrm{mV} . \mathrm{s}^{-1}$; third scan is shown.

\section{Catalytic $\mathrm{CO}_{2}$ electroreduction studies}

The $\mathrm{CV}$ of a solution of complex $\mathbf{2} \mathbf{b}$ did not change upon saturation with $\mathrm{CO}_{2}$, in the absence of a source of protons (Figure 4). Addition of $2 \mathrm{M}$ trifluoroethanol (TFEH) led to a large catalytic wave, however observed only on the $\mathrm{Hg} / \mathrm{Au}$ electrode (Figure 4). Indeed a large difference between the glassy carbon electrode (GCE) and the $\mathrm{Hg} / \mathrm{Au}$ electrodes was observed (Figure S6). This behavior is reminiscent of that observed in the case of the $\left[\mathrm{Ni}(\text { cyclam) }]^{2+}\right.$ complex. In that case, it was proposed that favorable interactions between the complex and the $\mathrm{Hg}$ surface of the electrode resulted in a dramatic enhancement of the catalytic efficiency of the complex. ${ }^{8,10,12}$ Therefore, herein we present only data obtained with the $\mathrm{Hg} / \mathrm{Au}$ electrode. 


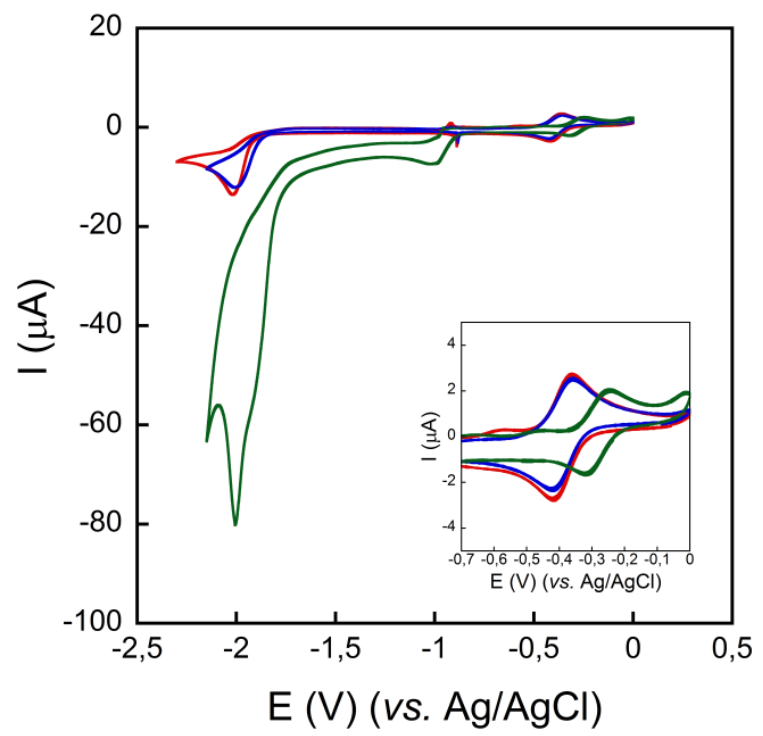

Figure 4. Cyclic voltammograms of $0.5 \mathrm{mM}$ of complex $\mathbf{2 b}$ under an $\mathrm{Ar}$ atmosphere (red line) and under a $\mathrm{CO}_{2}$ atmosphere, without (blue line) and with $2 \mathrm{M}$ TFEH (green line) in $\mathrm{CH}_{3} \mathrm{CN}$ with $0.1 \mathrm{M}$ TBAP. Scan rate $50 \mathrm{mV} . \mathrm{s}^{-1} ; \mathrm{Hg} / \mathrm{Au}$ amalgam electrode; third scan is shown. Inset: Zoom on the $\left[\mathrm{Ni}(\mathrm{qpdt})_{2}\right]^{-} /\left[\mathrm{Ni}(\mathrm{qpdt})_{2}\right]^{2-}$ wave.

Several features of the $\mathrm{CV}$ of $\mathbf{2} \mathbf{b}$ in $\mathrm{CH}_{3} \mathrm{CN}$ in the presence of $\mathrm{CO}_{2}$ and $2 \mathrm{M} \mathrm{TFEH}$ on

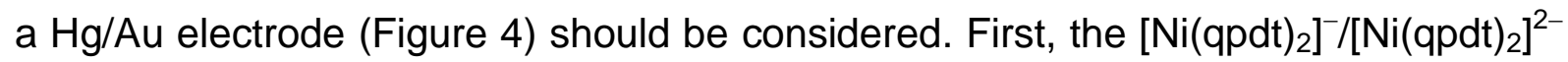
wave was shifted $120 \mathrm{mV}$ anodically indicating that reduction is eased by protonation. Second, the onset potential of the catalytic wave is at about $-1.7 \mathrm{~V}$, with a half-wave potential at $-1.80 \mathrm{~V}$ and a peak at $-2 \mathrm{~V}$, thus resulting in an overpotential of approximately $340 \mathrm{mV}$. Even though several products were formed, but with formate being the major product of the reaction (see below), the overpotential was determined by comparing the experimental onset potential to the standard potential of the $\mathrm{CO}_{2} / \mathrm{HCOOH}$ couple in $\mathrm{CH}_{3} \mathrm{CN}$ in the presence of TFEH as a proton source (see $\mathrm{SI}$ for calculation details). Third, a new irreversible wave was observed at $-1 \mathrm{~V}$. This feature is reminiscent of that observed in the CV of the [CpCo'"(qpdt)] complex (3), in an organic solvent and in the presence of a source of protons.$^{29}$ In that case we have clearly demonstrated, via electrolysis at this potential, isolation and characterization of the reaction product, that this redox feature corresponds to an O1-C2 bond cleavage of the pyran ring upon a 4-electron reduction of the dithiolene ligand (Scheme 1). 

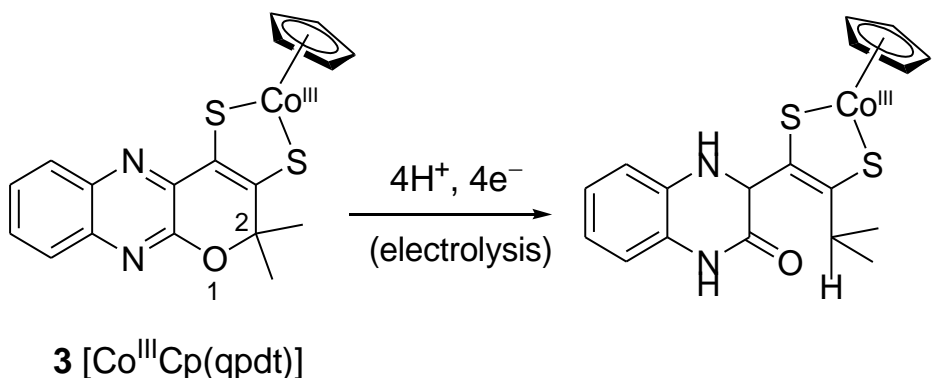

Scheme 1. O1-C2 bond cleavage of the pyran ring upon a 4-electron reduction of [CpCo'"'(qpdt)]. (ref. 26)

We have applied the same strategy for the $\left[\mathrm{Ni}^{\mathrm{ill}}(\mathrm{qpdt})_{2}\right]^{-}$complex, but we failed to isolate a stable product after electrolysis. However, at a low scan rate $\left(1 \mathrm{mV} . \mathrm{s}^{-1}\right)$, analysis of the irreversible wave at $-1 \mathrm{~V}$ allowed us to estimate that it fitted with an 8-electron process, most likely corresponding to the 4-electron reduction of each $\mathrm{qpdt}^{2-}$ ligand of complex $\mathbf{2 b}$ as in the case of the Co complex (Figure S7). Hence, the $\mathrm{CV}$ data indicate that complex $\mathbf{2 b}$ is in fact a catalyst precursor and that complex $\mathbf{4}$, derived from reduced $\mathbf{2} \mathbf{b}$, $\left[\mathrm{Ni}^{\prime \prime}(\mathrm{qpdt})_{2}\right]^{2-}$, through a full reduction of the ligand at the applied catalytic redox potential and subsequent pyran ring opening, is instead the real catalyst (Scheme 2). Accordingly, the CV of the solution after electrolysis showed that the initial complex $\mathbf{2} \mathbf{b}$ was no longer present and that another complex was formed. It is characterized by two quasi-reversible redox waves, at $+0.04 \mathrm{~V}$ and at $-0.8 \vee$ (Figure S8). We assigned these features to the $\mathrm{Ni}(\mathrm{IV}) / \mathrm{Ni}(\mathrm{III})$ and $\mathrm{Ni}(\mathrm{III}) / \mathrm{Ni} /(\mathrm{II})$ couples for complex $\mathbf{4}$. The cathodic shift of $\sim 550 \mathrm{mV}$ with respect to $\mathbf{2 b}$ is consistent with a more reduced ligand system.

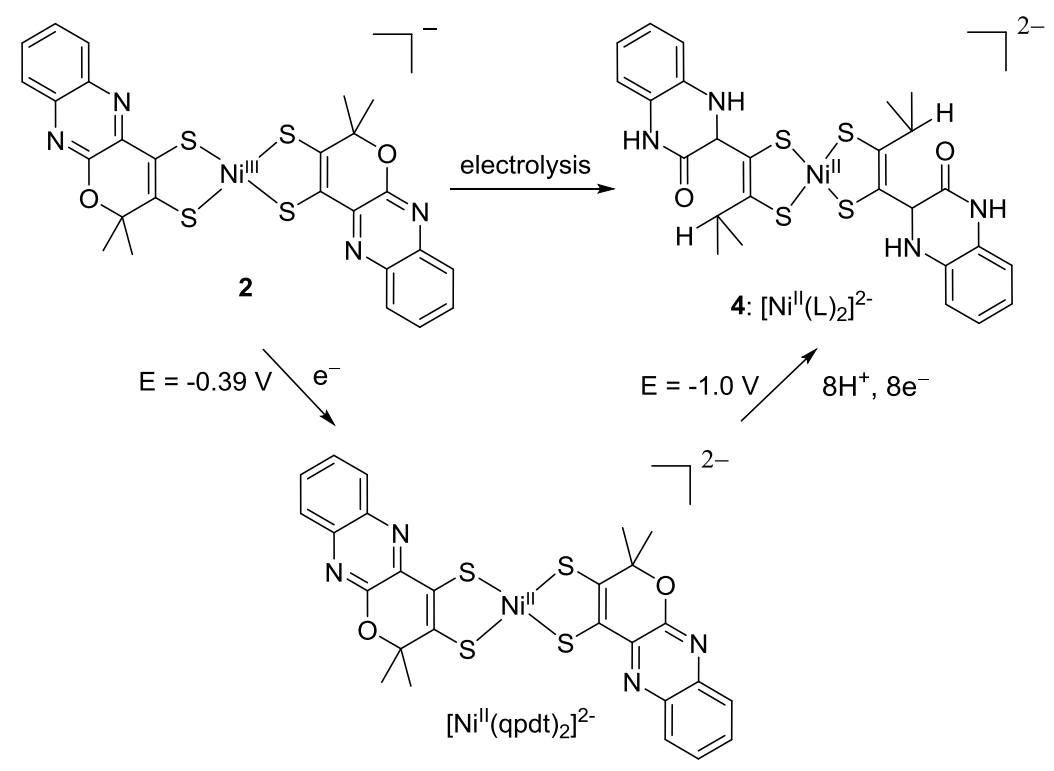


Scheme 2. Conversion of $\left[\mathrm{Ni}(\mathrm{qpdt})_{2}\right]^{-}$into complex 4 during electrochemical reduction.

Finally, in order to verify that no complex was permanently adsorbed on the $\mathrm{Hg}$ surface, a rinse test experiment was carried out. After 50 cycles in a solution containing $0.5 \mathrm{mM}$ complex and $2 \mathrm{M} \mathrm{TFEH}$ under $\mathrm{CO}_{2}$ atmosphere, the electrode was carefully rinsed and then assayed again in a freshly prepared solution without catalyst. As shown in Figure S9, no catalytic wave could be observed anymore. In order to evaluate the impact of the ligand on the observed activity, complex $\left(\mathrm{Bu}_{4} \mathrm{~N}\right)\left[\mathrm{Ni}^{\text {III }}\left(\mathrm{S}_{2} \mathrm{C}_{2} \mathrm{R}_{2}\right)_{2}\right] \quad\left(5, \mathrm{R}=\mathrm{CO}_{2} \mathrm{Me}\right)$, synthesized according to a previously published procedure, ${ }^{28}$ was studied and compared to complex $\mathbf{2 b}$. As it can be seen in Figure S10, no catalytic activity was found.

The reaction products were identified and monitored during electrolysis performed at - $1.9 \mathrm{~V}$ on a $1 \mathrm{~cm}$ diameter mercury pool working electrode (Figure S11). After 15 min, the current reached a value of about $-1.6 \mathrm{~mA}$ and remained stable for 4 hours. Formic acid was shown to be the main product ( 9 TONs after 4 hours and $60 \%$ faradaic yield $(\mathrm{FY})$ ). Minor amounts of $\mathrm{CO}(3 \mathrm{TONs}, 19 \%)$ and $\mathrm{H}_{2}(1.5 \mathrm{TONs}, 9 \%)$ were also formed, giving a total $\mathrm{FY}$ close to $90 \%$. Faradaic yields were calculated taking into account that $8 \mathrm{e}^{-}$are required up for the reduction of the ligands and that $2 \mathrm{e}^{-}$are mandatory to activate the metal center and initiate the catalysis. As observed in Figure S11, in the absence of catalyst the current was much less intense $(0.5 \mathrm{~mA})$ and the production of formate and carbon monoxide was negligible (Table S3). According to literature procedures, the electrolysis data were used to estimate a TOF value of $89 \mathrm{~s}^{-1}$ for the electrocatalytic reduction of $\mathrm{CO}_{2}$ at $-1.9 \mathrm{~V}$ (see SI for details of the calculation). ${ }^{30,31} \mathrm{~A}$ longer electrolysis $(23 \mathrm{~h}$ ) reveals the remarkable stability of the catalyst (Figure S12). The current was stabilized at $1 \mathrm{~mA}$ during the first 15 hours, after which it started to decrease. Product formation was sustained during the 23 hours of reaction leading to 38 TONs of formic acid (51\% FY) along with 7.5 TONs of $\mathrm{CO}(10 \%)$ and $6.5 \mathrm{TONs}$ of $\mathrm{H}_{2}(8.5 \%)$. Finally, the selectivity of the reaction was unchanged when electrolysis was performed at different potentials in the range of $1.75 \mathrm{~V}$ to $-2.1 \mathrm{~V}$.

Several control electrolysis experiments were carried out (Table S4). First, no $\mathrm{CO}_{2}$ reduction catalytic activity could be observed using $\mathrm{Ni}\left(\mathrm{ClO}_{4}\right)_{2}$ instead of complex $\mathbf{2 b}$, thus excluding the presence of active Ni particles derived from degradation of the 
complex during the reactions catalyzed by $\mathbf{2 b}$. Second, a rinse test showed that the complex was not irreversibly attached to the surface of the $\mathrm{Hg}$ pool. Third, when a $\mathrm{GC}$ electrode (1 $\mathrm{cm}$ diameter) was used as a working electrode, the current was not stable (Figure S13) and only very small amounts of products were detected (Table S4). Fourth, in agreement with the CV experiments (Figure S14), weaker acids such as $\mathrm{MeOH}$ or water failed to stimulate catalysis. Electrolysis at $-1.9 \mathrm{~V}$ for 4 hours in the presence of $2.7 \mathrm{M}$ of $\mathrm{H}_{2} \mathrm{O}$ or $2 \mathrm{M}$ of $\mathrm{MeOH}$ led to much lower formation of products, poor selectivity for the reduction of $\mathrm{CO}_{2}$ and low faradaic yields (Table S5). Large currents were observed in the presence of a stronger acid such as phenol (Figure S15), but a 4-hour electrolysis experiment at - $1.9 \mathrm{~V}$ (Table S5) revealed that they were essentially originating from proton reduction into $\mathrm{H}_{2}$. Finally, a larger concentration of TFEH $(3 \mathrm{M})$ resulted in increased production of $\mathrm{H}_{2}$, while a $0.5 \mathrm{M}$ TFEH solution was not acidic enough.

\section{Computational investigation of the $\mathrm{CO}_{2}$ reduction mechanism.}

Electronic structure of $\mathbf{2}$ and $\mathbf{4}$. The [Ni(qpdt) $\left.{ }_{2}\right]^{-}$complex $\mathbf{2}$ was fully optimized starting from its experimental X-ray crystal structure. Table S6 summarizes selected bond lengths and angles, showing that the two geometries are in excellent agreement (bond lengths are within $0.02 \AA$ of the values in the crystal structure and the bond angles are within $\left.1^{\circ}\right)$. The ground state of 2 is a doublet, which is in agreement with our EPR analysis (Figure S4). The unpaired electron is localized on the dithiolene moiety of the qpdt ${ }^{2-}$ ligands and has mainly $S_{3 p z}$ and $C_{2 p z}$ character as indicated by the SOMO orbital in Figure S16a. Due to the redox non-innocent nature of the dithiolene ligands, the structure can be represented by two resonance structures $\left[\mathrm{Ni}^{i \prime \prime}\left(\mathrm{qpdt}^{2-}\right)_{2}\right]^{-} \leftrightarrow\left[\mathrm{Ni}^{\prime \prime}\left(\mathrm{qpdt}^{2-}\right)\left(\mathrm{qpdt}^{-}\right)\right]^{-}$, with the radical anion character being the dominant form. Direct one-electron reduction to $\left[\mathrm{Ni}^{\prime \prime}(\mathrm{qpdt})_{2}\right]^{2-}$ is computed to occur at a potential of $E^{0}=-0.69 \mathrm{~V} v \mathrm{~s}$. $\mathrm{Ag} / \mathrm{AgCl}$ electrode (experimental $E^{0}=-0.39 \mathrm{~V}$ ). The $\mathrm{Ni}$ ion remains as a $\mathrm{Ni}^{\prime \prime}$ center because the extra electron goes to a dithiolene ligand orbital (Figure S16b). The [Ni(qpdt) $]_{2}^{2-}$ system has a closed-shell singlet ground state $(S=0)$, while the triplet state is $5.7 \mathrm{kcal} \mathrm{mol}^{-1}$ higher in energy. The square-planar structure of complex $\mathbf{2}$ is preserved in its one-electron reduced form accompanied by elongation of the $\mathrm{Ni}-\mathrm{S}$ bond lengths by $\sim 0.03 \AA$ (Table S6). 
Since the real catalyst is likely complex $\mathbf{4}$, all further DFT computations have been performed with 4, referred here as $\left.\mathrm{Ni}^{\mathrm{Il}}(\mathrm{L})_{2}\right]^{2-}$, $\mathrm{L}$ being the open ligand (Scheme 2). 4 has a singlet ground state, which is $4.5 \mathrm{kcal} \mathrm{mol}^{-1}$ more favored than the triplet state. Moreover, inspection of the bond lengths and angles (Table S6) indicates that the geometry of its $\mathrm{Ni}$ dithiolene moiety remains very similar to that of the one-electron reduced complex 2, $\left[\mathrm{Ni}^{\prime \prime}(\mathrm{qpdt})_{2}\right]^{2-}$. Electron reduction of $\mathbf{4}$ occurs at a computed reduction potential $E^{0}=-2.31 \mathrm{Vvs}$. $\mathrm{Ag} / \mathrm{AgCl}$ and leads to the formation of a $\left.\mathrm{Ni}^{\prime}(\mathrm{L})_{2}\right]^{3-}$ species bearing a $\mathrm{Ni}^{l}$ center (see Figure S17), along with a significant elongation of the Ni-S bonds by $\sim 0.15 \AA$ (Table S6).

$\mathrm{CO}_{2}$ adducts. While only side-on $\eta^{2}-\mathrm{CO}_{2}$ nickel structures have been reported to date, ${ }^{32-35}$ most theoretical studies on low-coordinate $\mathrm{Ni}$ centers revealed that both $\eta^{1}$ $\mathrm{CO}_{2}$ and $\eta^{2}-\mathrm{CO}_{2}$ are energetically favored coordination modes. ${ }^{36-38}$ In this work, we have located two different binding modes of $\mathrm{CO}_{2}$ to the Ni center, namely the $\eta^{1}-\mathrm{CO}_{2}$ and $\eta^{1}$-OCO. Comparison of their geometries and binding parameters are given in Table S7. Our calculations strongly favor the $\eta^{1}-\mathrm{CO}_{2}$ binding mode in $\left[\mathrm{Ni}\left(\eta^{1}-\right.\right.$ $\left.\left.\mathrm{CO}_{2}\right)(\mathrm{L})_{2}\right]^{3-}$, while the $\eta^{1}-\mathrm{OCO}$ adduct, $\left[\mathrm{Ni}\left(\eta^{1}-\mathrm{OCO}\right)(\mathrm{L})_{2}\right]^{3-}$, is $19 \mathrm{kcal} \mathrm{mol}^{-1}$ higher in energy. We could not locate a stable $\eta^{2}-\mathrm{CO}_{2}$ complex, as during the geometry optimization the initial $\left[\mathrm{Ni}\left(\eta^{2}-\mathrm{CO}_{2}\right)(\mathrm{L})_{2}\right]^{3-}$ structure rearranges to the stable $\left[\mathrm{Ni}\left(\eta^{1}-\right.\right.$ $\left.\mathrm{CO}_{2}(\mathrm{~L})_{2}\right]^{3-}$ one. It is important to note that no $\mathrm{CO}_{2}$ adduct can be formed starting from complex 4. Instead, a one-electron reduction step has to take place in order to create the active intermediate $\left[\mathrm{Ni}^{\prime}(\mathrm{L})_{2}\right]^{3-}$, which can further undergo two possible reaction pathways, as depicted in Figure 5 (vide infra).

The $\left[\mathrm{Ni}\left(\eta^{1}-\mathrm{CO}_{2}\right)(\mathrm{L})_{2}\right]^{3-} \mathrm{CO}_{2}$ adduct is characterized by a bending of the $\mathrm{CO}_{2}$ molecule when coordinated to the $\mathrm{Ni}$ center, with a $\mathrm{O}-\mathrm{C}-\mathrm{O}$ angle of $\sim 135^{\circ}$. Additionally, the two $\mathrm{C}-\mathrm{O}$ bonds are considerably elongated by $\sim 0.07 \AA$ and resemble those for $\mathrm{CO}_{2}{ }^{--}$ (Table S7). Molecular orbital (MOs) analysis shows that the electronic structure of $\left[\mathrm{Ni}\left(\eta^{1}-\mathrm{CO}_{2}\right)(\mathrm{L})_{2}\right]^{3-}$ is best described as $\mathrm{Ni}^{11}-\mathrm{CO}_{2}{ }^{-}$, which implies that the electron reduction of $\mathrm{CO}_{2}$ is nearly completed (Figure $\mathrm{S} 18$ ).

DFT mechanistic pathways. The $\mathrm{CO}_{2}$ electrochemical reduction results in formation of formate, $\mathrm{CO}$, and $\mathrm{H}_{2}$, with formate being the main product. Figure 5 shows the DFT proposed mechanistic pathways towards the formation of the observed 
products. The $\eta^{1}$-OCO complex may directly transform into a nickel formate species $\left[\mathrm{Ni}(\mathrm{OCOH})(\mathrm{L})_{2}\right]^{2-}$ via uptake of a proton as suggested for $\mathrm{Ni}($ cyclam $)+{ }^{+13}$ However, as mentioned above, this $\left[\mathrm{Ni}\left(\eta^{1}-\mathrm{OCO}\right)(\mathrm{L})_{2}\right]^{3-}$ adduct is computed to be strongly disfavored and cannot be regarded on the operating route for the production of formate. Therefore, our calculations invoke a Ni-hydride intermediate $\left[\mathrm{Ni}^{11 \prime}(\mathrm{H})(\mathrm{L})_{2}\right]^{2-}$ as a catalytically relevant species. It is formed upon protonation of the reduced complex 4 and has a transition state barrier of $14.0 \mathrm{kcal} \mathrm{mol}^{-1}$ (computed with the TFEH homoconjugate complex as an explicit proton source). Its frontier molecular orbitals are shown in Figure S19. Exergonic by $7.3 \mathrm{kcal} \mathrm{mol}^{-1}$, the nickel hydride formation results in a $\mathrm{Ni}^{\text {III }}(\mathrm{H})$ center in a tetragonal coordination with respect to the two dithiolene ligands. Protonation of the different $S$ atoms is +1.0 and $+3.6 \mathrm{kcal} \mathrm{mol}^{-1}$ higher in energy. The $\left[\mathrm{Ni}^{\prime \prime \prime}(\mathrm{H})(\mathrm{L})_{2}\right]^{2-}$ species then reacts with $\mathrm{CO}_{2}$ and a transition state was located with a free energy of activation of only $7.1 \mathrm{kcal} \mathrm{mol}^{-1}$. Direct subtraction of the proton through an internal hydride transfer in the $\left[\mathrm{Ni} \cdots \mathrm{HCO}_{2}{ }^{-}\right]$ complex is followed by a release of $\mathrm{HCOO}^{-}\left(\Delta G=-32.9 \mathrm{kcal} \mathrm{mol}^{-1}\right)$ and regeneration of the catalyst 4 upon one-electron reduction step at $E^{0}=-0.51 \mathrm{~V}$ (red pathway in Figure 5). 


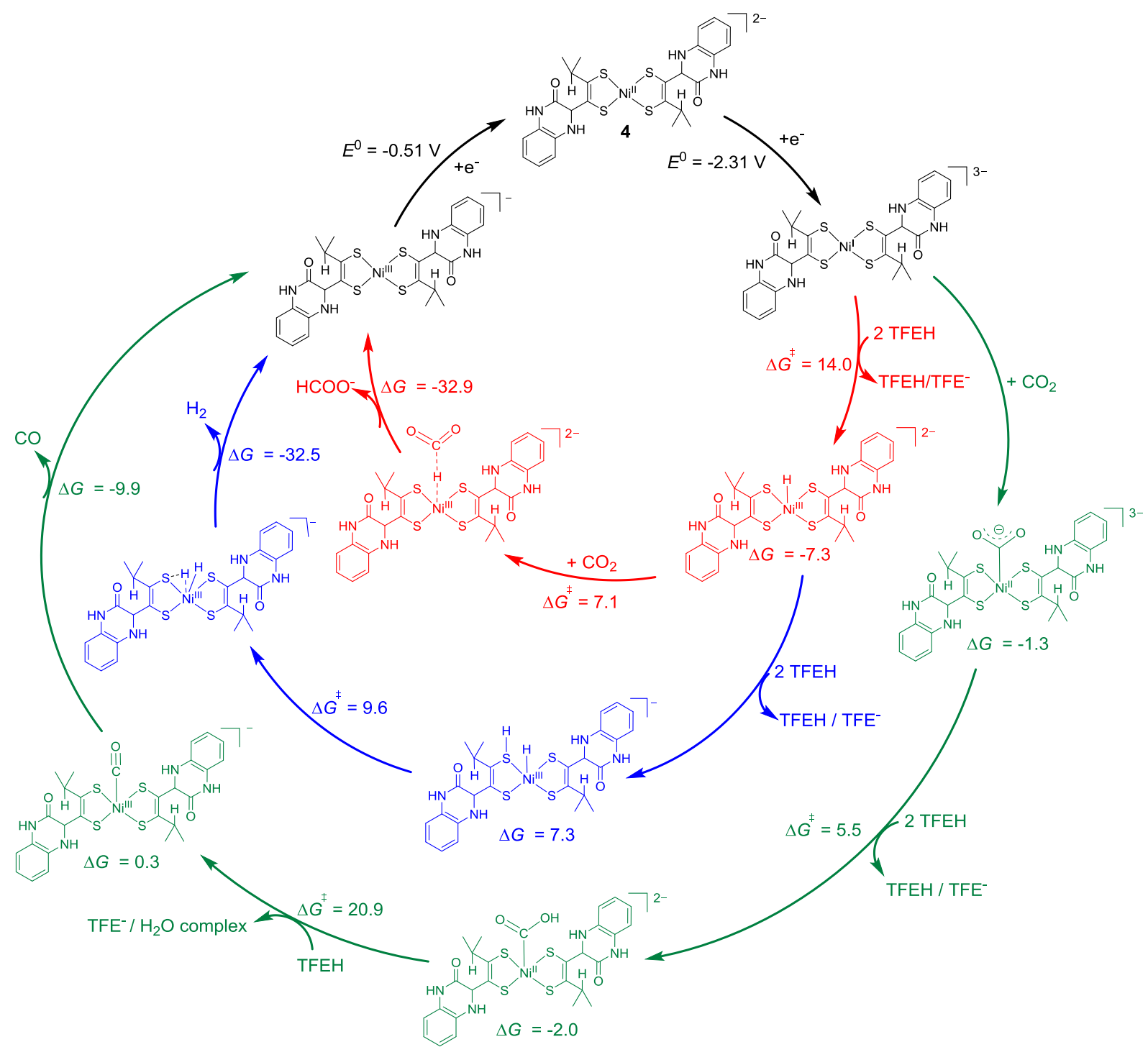

Figure 5. Proposed reaction mechanisms of $\mathrm{CO}_{2}$ reduction by complex 4 to formate (red), $\mathrm{H}_{2}$ (blue), and $\mathrm{CO}$ (green). The relative Gibbs free energies $\left(\Delta G, \mathrm{kcal} \mathrm{mol}^{-1}\right)$ and transition state barriers $\left(\Delta G^{\#}\right.$, $\mathrm{kcal} \mathrm{mol}^{-1}$ ) are reported relative to the preceding intermediate. Standard one-electron reduction potentials $\left(E^{0}, \mathrm{~V}\right)$ are given $v s . \mathrm{Ag} / \mathrm{AgCl}$ electrode.

The Ni-hydride $\left[\mathrm{Ni}^{\mathrm{III}}(\mathrm{H})(\mathrm{L})_{2}\right]^{2-}$ intermediate has a key role in the formation of $\mathrm{H}_{2}$. It can accept a second proton from the acid source to form $\left[\mathrm{Ni}^{\prime \prime \prime}(\mathrm{H})(\mathrm{SH})(\mathrm{L})_{2}\right]^{-}$species $(\Delta G=$ $\left.+7.3 \mathrm{kcal} \mathrm{mol}^{-1}\right)$. The protonation occurs on a sulfur atom from the dithiolene ligand with an $\mathrm{S}-\mathrm{H}$ bond syn to the $\mathrm{Ni}-\mathrm{H}$ bond. This species is well set to release hydrogen with a computed transition state barrier of $9.6 \mathrm{kcal} \mathrm{mol}^{-1}$ (blue pathway in Figure 5). Finally, the small amount of $\mathrm{CO}$ observed during the electrolysis can be explained by the reaction pathway (green pathway in Figure 5) proceeding through the $\eta^{1}-\mathrm{CO}_{2}$ species $\left(\Delta G=-1.3 \mathrm{kcal} \mathrm{mol}^{-1}\right)$. First, a protonation to the carboxylate intermediate $\left[\mathrm{Ni}(\mathrm{C}(\mathrm{O}) \mathrm{OH})(\mathrm{L})_{2}\right]^{2-}$ takes place $\left(\Delta G=-2.0 \mathrm{kcal} \mathrm{mol}^{-1}\right)$ and a transition state was 
located with a free energy of activation of $5.5 \mathrm{kcal} \mathrm{mol}^{-1}$ (frontier MOs are shown in Figure S20). Subsequently, in the presence of another proton the carboxylate undergoes a heterolytic $\mathrm{C}-\mathrm{O}$ bond cleavage to generate $\left.\left[\mathrm{Ni}(\mathrm{CO})_{(\mathrm{L}}\right)_{2}\right]^{-}$. This is the rate-limiting step, since the computed TS barrier amounts to $20.9 \mathrm{kcal} \mathrm{mol}^{-1}$. The value is very similar to the corresponding barriers computed for $\mathrm{CO}_{2}$ reduction by $\mathrm{Ni}(\text { cyclam })^{+}\left(20.9 \mathrm{kcal} \mathrm{mol}^{-1}\right),{ }^{13}\left[\operatorname{Re}(\mathrm{bpy})(\mathrm{CO})_{3}\right]\left(22.5 \mathrm{kcal} \mathrm{mol}^{-1}\right),{ }^{39}$ as well as $\left[\mathrm{Mn}(\mathrm{bpy})(\mathrm{CO})_{3}\right]^{-}\left(22.2 \mathrm{kcal} \mathrm{mol}^{-1}\right) .{ }^{40}$ The reaction is followed by a release of a CO molecule $\left(\Delta G=-9.9 \mathrm{kcal} \mathrm{mol}^{-1}\right)$ and the recovery of complex 4 upon a one-electron reduction step.

\section{DISCUSSION}

Still only few classes of mononuclear complexes have been explored as catalysts for homogeneous $\mathrm{CO}_{2}$ electroreduction and quite surprisingly, among non-noble metals, $\mathrm{Ni}$ has been much less studied than $\mathrm{Co}$, Fe or $\mathrm{Mn}$. One exception is the $[\mathrm{Ni}(\text { cyclam })]^{2+}$ complex and derivatives which proved excellent catalysts for the selective electroreduction of $\mathrm{CO}_{2}$ into $\mathrm{CO} .{ }^{41}$ Complex 2, [Ni(qpdt) $\left.)_{2}\right]^{-}$, reported here thus opens new perspectives in $\mathrm{Ni}$-based $\mathrm{CO}_{2}$ electroreduction catalysis as it shows that a $\mathrm{Ni}$ ion coordinated exclusively by $\mathrm{S}$ atoms (here $\mathrm{NiS}_{4}$ ) displays very interesting catalytic performances. The only related precedent, reported during the course of this study, is a Ni complex bearing an $\mathrm{S}_{2} \mathrm{~N}_{2}$-type tetradentate ligand which was shown to catalyze $\mathrm{CO}_{2}$ reduction into $\mathrm{CO}$ in a photocatalytic system. Sulfur coordination to $\mathrm{Ni}$ is in fact one of the solutions found by Nature for interconverting $\mathrm{CO}_{2}$ and $\mathrm{CO}$, within [NiFe] CO-dehydrogenases (CODHs). Even though the NiFe cluster in $\mathrm{CODH}$ is much more complex than the synthetic compound 2, exquisite biochemical and structural data have suggested the unique $\mathrm{Ni}$ center to play a major redox role during the enzyme reaction. ${ }^{18}$ In a way, the demonstration here that catalysis for $\mathrm{CO}_{2}$ reduction can be promoted just by a mononuclear S-coordinated $\mathrm{Ni}$ complex provides further support to the hypothesis that $\mathrm{Ni}$ is the only redox-active site in $\mathrm{CODH}$ and that the dangling $\mathrm{Fe}$ atom rather serves as a Lewis acid for polarizing a $\mathrm{C}-\mathrm{O}$ bond for subsequent cleavage. As it is the first and unique example of this class of complexes, there are a lot of open questions regarding the influence of the ligands on the reactivity. Indeed, here a special ligand has been used, namely qpdt $^{2-}$, a molecule containing a bidentate dithiolene moiety and mimicking the molybdopterin ligand 
present in formate dehydrogenases and $[\mathrm{MoCu}] \mathrm{CODH}$. The absence of activity found with complex 5 , bearing a simpler dithiolene ligand, proves that the ligand is playing a role in the catalysis and that it is not general to any $\mathrm{Ni}$ (bis-dithiolene) complex. Obviously, other S-based ligands need to be further investigated.

One implication of using this particular ligand resides in the fact that complex 2 is a catalyst precursor and complex $\mathbf{4}$ is the actual catalyst (Scheme 2). Indeed, we have shown that, when coordinated to a metal ion, qpdt ${ }^{2-}$ undergoes a 4-electron reduction of its pyrazine ring at potential values more positive than that required for catalysis, followed by the opening of the pyran ring, leading to a new stable dithiolene ligand (L). As a consequence, DFT calculations aiming at getting insights into the $\mathrm{CO}_{2}$ reduction mechanism have been carried out using complex 4 .

A final comment with respect to the true nature of the catalyst considers the importance of a mercury electrode for stimulating the catalytic activity of the $\mathrm{Ni}$ complex. Indeed, catalytic activity was dramatically enhanced on such an electrode as compared to a standard glassy carbon electrode. There are several precedents of $\mathrm{Ni}$ complexes, with a variety of ligands such as bipyridine, ${ }^{42}$ glyoxime ${ }^{43}$ and salen $^{44}$ adsorbing at $\mathrm{Hg}$ electrodes. But the most relevant example in the context of $\mathrm{CO}_{2}$ reduction catalysis is $[\mathrm{Ni}(\text { cyclam })]^{2+}$ complex. A recent study ${ }^{10}$ established that the dramatic increase in catalytic activity on mercury was due to favorable non-covalent interactions between the cyclam ligand and the surface of the mercury electrode, leading to the adsorption of the most active conformer and encouraging $\mathrm{CO}_{2}$ binding. Additionally this facilitates $\mathrm{CO}$ desorption, the limiting step of the reaction, thus limiting $\mathrm{CO}$ poisoning. Even though this needs to be studied, we believe that similar scenarios are at work in the case of the $\mathrm{Ni}$ complex. Nevertheless, these observations suggest that specific non-covalent interactions between homogeneous catalysts and metallic surfaces, very little studied so far, play important roles, thus opening perspectives for improving catalytic performances.

The characteristics of the reaction catalyzed by complex $\mathbf{2}$ are the following: (i) catalysis starts at an onset potential corresponding to an overpotential of only 340 $\mathrm{mV}$; (ii) electrolysis generates formate as the major product together with small amounts of $\mathrm{CO}$ and $\mathrm{H}_{2}$ with good total faradaic yields close to $90 \%$; (iii) the selectivity of the system can be optimized via an appropriate choice of the proton donor, with 
TFEH providing the best balance for preventing too large production of $\mathrm{H}_{2}$; (iv) the system is remarkably stable since sustained reduction of $\mathrm{CO}_{2}$ was achieved during an electrolysis experiment of $23 \mathrm{~h}$ (Figure S11). At first sight, it seems that the system suffers from low selectivity.

Formation of formic acid as the major product is to be noted. While several Rh-, Ruand Ir-based complexes have been shown to catalyze the electroreduction of $\mathrm{CO}_{2}$ to formic acid, ${ }^{4,5}$ examples based on non-noble metals are rare. This has been reported mainly in the case of $\mathrm{Fe}$ complexes ${ }^{45-47}$ and a series of CpCo-diphosphine complexes. ${ }^{48} \mathrm{Ni}$ and $\mathrm{Mn}$ complexes are known to produce exclusively $\mathrm{CO}$ except under very particular conditions which promote formate production. ${ }^{49,50}$ In the specific case of the $[\mathrm{Ni}(\text { cyclam })]^{2+}$ complex, it has been shown that even after reduction, the complex is not basic enough to react with protons and thus formation of a hydride $\mathrm{Ni}$ $\mathrm{H}$ species, the generally proposed precursor for $\mathrm{HCOOH}$ and $\mathrm{H}_{2}$ evolution, is excluded. ${ }^{13}$ This thus explains the high selectivity of the catalyst for $\mathrm{CO}$ production: the nucleophilic reduced complex reacts exclusively with $\mathrm{CO}_{2}$, giving an $\eta^{1}-\mathrm{CO}_{2}$ adduct acting as a precursor of $\mathrm{CO} .{ }^{13}$ In DMF, formation of formic acid can therefore be explained only by formation and protonation of a $\eta^{1}$-OCO adduct, however strongly destabilized with regard to the former adduct. ${ }^{13,50}$

In contrast, in the case of complex 4, DFT calculations reported here show that several pathways are possible, thus explaining the formation of the 3 products, i.e., formic acid, $\mathrm{CO}$ and $\mathrm{H}_{2}$ (Figure 5). The reduced active $\left[\mathrm{Ni}^{1}(\mathrm{~L})_{2}\right]^{3-}$ intermediate can not only react directly with $\mathrm{CO}_{2}$, opening the way to $\mathrm{CO}$, as in the case of the $[\mathrm{Ni}(\text { cyclam })]^{2+}$ complex, but also to a Ni-hydride intermediate, which is responsible for the formation of formic acid and $\mathrm{H}_{2}$. This is likely due to the stronger electrondonating properties of the dithiolene ligand in complex $\mathbf{4}$, which allow the formation of a Ni-hydride intermediate, reactive enough to generate both formate and $\mathrm{H}_{2}$ by reaction with $\mathrm{CO}_{2}$ and $\mathrm{H}^{+}$, respectively.

\section{CONCLUSIONS}

This study demonstrates for the first time that a molecular $\mathrm{Ni}$ (bis-dithiolene) complex has the potential to function as a rather efficient and stable catalyst for the electroreduction of $\mathrm{CO}_{2}$. While it indeed opens the way to a new class of $\mathrm{CO}_{2}$ reduction catalysts, investigation of a broader range of $\mathrm{Ni}$ complexes, with $\mathrm{NiS}_{x}$ 
coordination, is needed to better understand structure-activity relationships and to optimize such systems.

\section{AUTHOR INFORMATION}

\section{Corresponding Author}

*E-mail: yun.xu-li@college-de-france.fr;

^E-mail: marc.fontecave@college-de-france.fr

ORCID

Yun LI : 0000-0003-4805-7156.

Marc Fontecave : 0000-0002-8016-4747.

Maria Gomez-Mingot : 0000-0002-1557-2648.

\section{Notes}

The authors declare no completing financial interest.

\section{ASSOCIATED CONTENT}

\section{Supporting Information}

The Supporting Information is available free of charge on the ACS Publications website at http://pubs.acs.org:

Electrochemical characterizations of complexes 2, along with catalytic studies. Frontier molecular orbitals of 2 and $\mathbf{4}$, the $\eta^{1}-\mathrm{CO}_{2}$ adduct $\left[\mathrm{Ni}\left(\eta^{1}-\mathrm{CO}_{2}\right)(\mathrm{L})_{2}\right]^{3-}$, $\left[\mathrm{Ni}(\mathrm{C}(\mathrm{O}) \mathrm{OH})(\mathrm{L})_{2}\right]^{2-}$ and the Ni-hydride $\left[\mathrm{Ni}^{\mathrm{III}}(\mathrm{H})(\mathrm{L})_{2}\right]^{2-}$, geometrical parameters for $\mathbf{2 , 4}$ and their reduced complexes, as well as geometrical and binding parameters for the located $\mathrm{CO}_{2}$ adducts, xyz coordinates of all intermediates.

\section{ACKNOWLEDGEMENTS}

This work was supported by the French National Research Agency (CarBioRed ANR12-BS07-0024-03, PhotoCarb ANR-16-CE05-0025-01), the Fondation de l'Orangerie 
for individual Philanthropy, the French State Program 'Investissements d'Avenir' (Grants "LABEX DYNAMO", ANR-11-LABX-0011). We are grateful to E. Galardon (University of Paris Descartes) and S. Blanchard (University of Pierre Marie Curie) for EPR analysis. We thank L. Dubost (Museum National d'Histoire Naturelle) for technical support and $\mathrm{P}$. Simon for various $\mathrm{CO}_{2}$ reduction products detection methods. The calculations were performed using the iDataPlex cluster of the UPMC DSI computing center and the HPC resources of GENCI (TGCC) through Grant 2017-810082.

\section{EXPERIMENTAL SECTION}

\section{General Considerations}

All reagents and solvents were used as received unless otherwise specified. Aqueous solutions were prepared with doubly deionized water with resistivity not less than $18.2 \mathrm{M} \Omega \mathrm{cm}-1$. Anhydrous acetonitrile $\left(\mathrm{CH}_{3} \mathrm{CN}\right)$, tetra- $n$-butylammonium perchlorate were purchased from Sigma-Aldrich and used as received.

All ${ }^{1} \mathrm{H}$ NMR experiments were conducted on a Bruker $300 \mathrm{MHz}$ instrument and the UV-vis spectra were recorded using a Cary 100 UV-vis spectrophotometer instrument (Agilent). Mass spectrometry analysis and electrospray Q-TOF (ES QTOF MS) were performed on a Q-star instrument (Applied Biosystem).

\section{Synthesis of $\left(\mathrm{PPh}_{4}\right)\left[\mathrm{Ni}^{\mathrm{ill}}(\mathrm{qpdt})_{2}\right](2 \mathrm{a})$}

The experiment was carried out under Ar using Schlenk tubes and all solutions were degassed prior to use. tBuOK (189 mg, $1.67 \mathrm{mmol}$ ) was added to a solution of 1 (200 mg, $0.420 \mathrm{mmol})$ in anhydrous THF (4 mL). After $15 \mathrm{~min}$ at room temperature, a solution of $\mathrm{Ni}\left(\mathrm{ClO}_{4}\right)_{2} \cdot 6 \mathrm{H}_{2} \mathrm{O}(76 \mathrm{mg}, 0.210 \mathrm{mmol})$ in $\mathrm{MeOH}(1 \mathrm{~mL})$ was added dropwise via a cannula needle to the dark red suspension. An immediate color change to black was observed. After $30 \mathrm{~min}, \mathrm{PPh}_{4} \mathrm{Cl}(157 \mathrm{mg}$, $0.42 \mathrm{mmol}$ ) was added and the dark green solution was kept at room temperature for $3 \mathrm{~h}$. After evaporation of solvents, the dark green precipitate was dissolved in $\mathrm{CH}_{3} \mathrm{CN}$, filtered and evaporated to dryness. The crude product was purified by flash chromatography over silica gel (eluting with $\left.\mathrm{MeOH}: \mathrm{CH}_{2} \mathrm{Cl}_{2}, 1: 99\right)$ gave a dark green solid (103 mg, $52 \%)$. UV-Vis $\left(\mathrm{CH}_{3} \mathrm{CN}\right), \lambda_{\max } \mathrm{nm}\left(\varepsilon, \mathrm{M}^{-1} \mathrm{~cm}^{-1}\right): 975$ (18240), 627 (6400), 410 (37040), 392 (34400). 
Negative-ion ESI-MS $\left(\mathrm{CH}_{3} \mathrm{CN}\right): \mathrm{m} / \mathrm{z}=605.98\left(\left[\mathrm{Ni}(\mathrm{qpdt})_{2}\right]^{-}\right)$; Anal. Calcd for $\mathrm{C}_{50} \mathrm{H}_{40} \mathrm{~N}_{4} \mathrm{NiO}_{2} \mathrm{PS}_{4}$ (946.8054): C 63.43, H 4.26, N 5.92, S 13.55; Found: C 63.60, H 4.08, N 5.82, S 13.67. Single crystals suitable for X-ray diffraction were obtained by layering pentane over a $\mathrm{CH}_{2} \mathrm{Cl}_{2}$ solution containing the crude complex at room temperature.

\section{Synthesis of $\left(\mathrm{Bu}_{4} \mathrm{~N}\right)\left[\mathrm{Ni}{ }^{\text {III }}(\mathrm{qpdt})_{2}\right](2 \mathrm{~b})$}

The same procedure was applied except that $n \mathrm{Bu}_{4} \mathrm{NBr}$ was used instead of $\mathrm{PPh}_{4} \mathrm{Cl}$. Anal. Calcd for $\mathrm{C}_{42} \mathrm{H}_{56} \mathrm{~N}_{5} \mathrm{NiO}_{2} \mathrm{~S}_{4}$ (849.8764): $\mathrm{C} 59.36, \mathrm{H} 6.64, \mathrm{~N}$ 8.24, $\mathrm{S}$ 15.09; Found: C 59.33, H 6.40, N 8.22, S 15.03.

\section{Electrochemical experiments}

All cyclic voltammetry (CVs) experiments were performed in a conventional threeelectrode single-compartment cell with a SP 300 Bio-Logic potentiostat (Bio-Logic Science Instruments SAS). A saturated $\mathrm{Ag} / \mathrm{AgCl} / \mathrm{KCl}$ electrode (hereafter abbreviated as $\mathrm{Ag} / \mathrm{AgCl}$ ) was placed in the same compartment as the working electrode separated by a bridge with a Vycor frit and was used as the reference electrode. A platinum counter electrode was separated from the solution by a glass frit. Glassy carbon electrode (GCE from BASi) of $1 \mathrm{~mm}$ diameter or $\mathrm{Hg} / \mathrm{Au}$ amalgam electrode were used as working electrodes. The $\mathrm{Hg} / \mathrm{Au}$ amalgam electrode was prepared by dipping a $1.6 \mathrm{~mm}$ diameter disk $\mathrm{Au}$ electrode (BASi) into a pool of mercury. Electrodes were polished on wet polishing cloth using a $1 \mu \mathrm{m}$ diamond suspension and a $0.05 \mu \mathrm{m}$ alumina slurry. The scan rate was $50 \mathrm{mV} . \mathrm{s}^{-1}$. Solutions of dry acetonitrile containing $0.1 \mathrm{M}$ tetrabutylammonium perchlorate (TBAP) as the supporting electrolyte were bulk deaerated with Ar for at least 15 min before CVs. Bulk electrolysis experiments were carried out at room temperature in a custom-built, gas-tight two-compartment electrochemical cell specific for mercury that has been previously described.$^{25}$ The cathodic and anodic compartments are separated via a porous glass frit of fine porosity. . Bulk solutions, constantly stirred, of $0.5 \mathrm{mM}$ of catalysts and $2 \mathrm{M}$ of trifluoroethanol (TFEH) in acetonitrile containing 0.1 M TBAP were purged with $\mathrm{CO}_{2}$ gas for 30 min before starting the experiment. The working electrode was a pool of $0.5 \mathrm{~mL}$ of mercury, the counter electrode was a $0.5 \mathrm{~mm}$ diameter platinum wire and the reference electrode was a saturated $\mathrm{Ag} / \mathrm{AgCl} / \mathrm{KCl}$ electrode. Carbon monoxide was detected with a gas chromatograph (Shimadzu GC2010) equipped with a methanizer, a flame induction detector (FID), and a shincarbon ST (Restek) column. Formic acid concentrations were determined by 
ionic exchange chromatography (883 Basic IC, Metrohm). $\mathrm{H}_{2}$ was detected a gas chromatograph coupled to a thermal conductivity detector (Shimadzu GC-2014). Aliquots of gas were removed with a gas-tight syringe.

\section{Computational Methods}

All geometries were fully optimized at the B3P86 $6^{51,52} / 6-311+G(d, p)^{53,54}$ level of density functional theory (DFT) using the Gaussian 09 program $^{55}$ and the SMD implicit-solvation model, ${ }^{56}$ for which acetonitrile $(\varepsilon=35.688)$ was chosen as the solvent, consistent with the experiment. Unrestricted Kohn-Sham formalism was used to explore the spin multiplicity of the investigated adducts. Harmonic vibrational frequencies were computed on the optimized geometries to ensure that all local minima display real frequencies only, whereas the transition states were characterized by a single imaginary frequency. The zero-point vibrational energies, thermal corrections and entropy terms for the optimized geometries were obtained from the frequency calculations. Reduction potentials were calculated using the equation $E^{0}=\left(-\frac{\Delta G^{0}}{n F}\right)-E_{r e f}^{0}$, where $n$ is the number of transferring electrons, $F$ is Faraday's constant, $\Delta G^{0}$ is the free energy of reduction, corrected by $1.89 \mathrm{kcal} \mathrm{mol}^{-1}$ for the $1 \mathrm{~atm}$ to $1 \mathrm{M}$ standard-state concentration change, and $E_{r e f}^{0}$ is the absolute reduction potential of the reference species, (the ferrocenium/ferrocene couple $\left.\left(\mathrm{Fc}^{+} / \mathrm{Fc}\right)\right)$, computed at the same level of theory. The thus obtained reduction potentials were then converted to values $v s$. the $\mathrm{Ag} / \mathrm{AgCl}$ electrode by adding $0.5 \mathrm{~V}$. The free energy of reactions involving protons was calculated by explicitly considering the equilibria among TFEH and TFE/TFEH homoconjugate, and one or two TFEH molecules were used as an explicit proton source for the transition state barrier computations. 


\section{REFERENCES}

1. Elgrishi, N.; Chambers, M. B.; Wang, X.; Fontecave, M. Chem. Soc. Rev. 2017, 46, 761-796.

2. Takeda, H.; Cometto, C.; Ishitani, O.; Robert, M. ACS Catal. 2017, 7, 70-88.

3. Elgrishi, N.; Chambers, M. B.; Fontecave, M. Chem. Sci. 2015, 6, 2522-2531.

4. Windle, C. D.; Perutz, R. N. Coord. Chem. Rev. 2012, 256, 2562-2570.

5. $\quad$ Appel, A. M.; Bercaw, J. E.; Bocarsly, A. B.; Dobbek, H.; DuBois, D. L.; Dupuis, M.; Ferry, J. G.; Fujita, E.; Hille, R.; Kenis, P. J.; Kerfeld, C. A.; Morris, R. H.; Peden, C. H.; Portis, A. R.; Ragsdale, S. W.; Rauchfuss, T. B.; Reek, J. N.; Seefeldt, L. C.; Thauer, R. K.; Waldrop, G. L. Chem. Rev. 2013, 113, 66216658.

6. Costentin, C.; Robert, M.; Saveant, J. M. Acc. Chem. Res. 2015, 48, 2996-3006.

7. Smieja, J. M.; Sampson, M. D.; Grice, K. A.; Benson, E. E.; Froehlich, J. D.; Kubiak, C. P. Inorg. Chem. 2013, 52, 2484-2491.

8. Beley, M.; Collin, J.-P.; Ruppert, R.; Sauvage, J.-P. J. Chem. Soc., Chem. Commun. 1984, 13151316.

9. Beley, M.; Collin, J. P.; Ruppert, R.; Sauvage, J. P. J. Am. Chem. Soc. 1986, 108, 7461-7467.

10. Froehlich, J. D.; Kubiak, C. P. Inorg. Chem. 2012, 51, 3932-3934.

11. Froehlich, J. D.; Kubiak, C. P. J. Am. Chem. Soc. 2015, 137, 3565-3573.

12. Wu, Y.; Rudshteyn, B.; Zhanaidarova, A.; Froehlich, J. D.; Ding, W.; Kubiak, C. P.; Batista, V. S. ACS Catal. 2017, 7, 5282-5288.

13. Song, J.; Klein, E. L.; Neese, F.; Ye, S. Inorg. Chem. 2014, 53, 7500-7507.

14. Fisher, B.; Eisenberg, R. J. Am. Chem. Soc. 1980, 102, 7361-7363.

15. Kuehnel, M. F.; Orchard, K. L.; Dalle, K. E.; Reisner, E. J. Am. Chem. Soc. 2017, 139, 7217-7223.

16. Thoi, V. S.; Kornienko, N.; Margarit, C. G.; Yang, P.; Chang, C. J. J. Am. Chem. Soc. 2013, 135, 14413-14424.

17. Hong, D.; Tsukakoshi, Y.; Kotani, H.; Ishizuka, T.; Kojima, T. J. Am. Chem. Soc. 2017, 139, 65386541.

18. Jeoung, J.-H.; Dobbek, H. Science 2007, 318, 1461-1464.

19. Stein, B. W.; Kirk, M. L. J. of Biol. Inorg. Chem. 2015, 20, 183-194.

20. Dobbek, H. Coord. Chem. Rev. 2011, 255, 1104-1116.

21. Moura, J. J. G.; Brondino, C. D.; Trincao, J.; Romao, M. J. J. Biol. Inorg. Chem. 2004, 9, 791799.

22. Das, A.; Han, Z.; Brennessel, W. W.; Holland, P. L.; Eisenberg, R. ACS Catal. 2015, 5, 13971406.

23. Zarkadoulas, A.; Field, M. J.; Papatriantafyllopoulou, C.; Fize, J.; Artero, V.; Mitsopoulou, C. A. Inorg. Chem. 2016, 55, 432-444.

24. Koshiba, K.; Yamauchi, K.; Sakai, K. Angew. Chem. Int. Ed. 2017, 56, 4247-4251.

25. Porcher, J. P.; Fogeron, T.; Gomez-Mingot, M.; Derat, E.; Chamoreau, L. M.; Li, Y.; Fontecave, M. Angew. Chem. Int. Ed. 2015, 54, 14090-14093.

26. Fogeron, T.; Porcher, J.-P.; Gomez-Mingot, M.; Todorova, T. K.; Chamoreau, L.-M.; MellotDraznieks, C.; Li, Y.; Fontecave, M. Dalton Trans. 2016, 45, 14754-14763.

27. Porcher, J. P.; Fogeron, T.; Gomez-Mingot, M.; Chamoreau, L. M.; Li, Y.; Fontecave, M. Chem. Eur. J. 2016, 22, 4447-4453.

28. Begum, A.; Moula, G.; Sarkar, S. Chem. Eur. J. 2010, 16, 12324-12327.

29. Fogeron, T.; Retailleau, P.; Chamoreau, L. M.; Fontecave, M.; Li, Y. Dalton Trans. 2017, 46, 4161-4164.

30. Chapovetsky, A.; Do, T. H.; Haiges, R.; Takase, M. K.; Marinescu, S. C. J. Am. Chem. Soc. 2016, $138,5765-5768$.

31. Costentin, C.; Drouet, S.; Robert, M.; Saveant, J. M. Science 2012, 338, 90-94.

32. Anderson, J. S.; Iluc, V. M.; Hillhouse, G. L. Inorg. Chem. 2010, 49, 10203-10207.

33. Beck, R.; Shoshani, M.; Krasinkiewicz, J.; Hatnean, J. A.; Johnson, S. A. Dalton Trans. 2013, 42, 1461-1475. 
34. Dohring, A.; Jolly, P. W.; Kruger, C.; Romão, M. J. Z. Naturforsch. B 2014, 40, 484-488.

35. Aresta, M.; Nobile, C. F.; Albano, V. G.; Forni, E.; Manassero, M. J. Chem. Soc., Chem. Commun. 1975, 636-637.

36. Sakaki, S.; Koga, N.; Morokuma, K. Inorg. Chem. 1990, 29, 3110-3116.

37. Dedieu, A.; Ingold, F. Angew. Chem. Int. Ed. Engl. 1989, 28, 1694-1695.

38. Sakaki, S. J. Am. Chem. Soc. 1992, 114, 2055-2062.

39. Keith, J. A.; Grice, K. A.; Kubiak, C. P.; Carter, E. A. J. Am. Chem. Soc. 2013, 135, 15823-15829.

40. Lam, Y. C.; Nielsen, R. J.; Gray, H. B.; Goddard, W. A. ACS Catal. 2015, 5, 2521-2528.

41. Schneider, J.; Jia, H. F.; Kobiro, K.; Cabelli, D. E.; Muckerman, J. T.; Fujita, E. Energy Environ. Sci. 2012, 5, 9502-9510.

42. Sawamoto, H. J. Electroanal. Chem. Interfacial Electrochem. 1980, 113, 301-304.

43. Ramirez, S.; Gordillo, G. J.; Posadas, D. J. Electroanal. Chem. 1996, 407, 219-225.

44. Farias, P. A. M.; Bastos, M. B. R. Int. J. Electrochem. 2013, 2013, 1-7.

45. Chen, L. J.; Guo, Z. G.; Wei, X. G.; Gallenkamp, C.; Bonin, J.; Anxolabehere-Mallart, E.; Lau, K. C.; Lau, T. C.; Robert, M. J. Am. Chem. Soc. 2015, 137, 10918-10921.

46. Taheri, A.; Thompson, E. J.; Fettinger, J. C.; Berben, L. A. ACS Catal. 2015, 5, 7140-7151.

47. Pun, S. N.; Chung, W. H.; Lam, K. M.; Guo, P.; Chan, P. H.; Wong, K. Y.; Che, C. M.; Chen, T. Y.; Peng, S. M. J. Chem. Soc., Dalton Trans. 2002, 575-583.

48. Roy, S.; Sharma, B.; Peaut, J.; Simon, P.; Fontecave, M.; Tran, P. D.; Derat, E.; Artero, V. J. Am. Chem. Soc. 2017, 139, 3685-3696.

49. Collin, J. P.; Jouaiti, A.; Sauvage, J. P. Inorg. Chem. 1988, 27, 1986-1990.

50. Franco, F.; Cometto, C.; Vallana, F. F.; Sordello, F.; Priola, E.; Minero, C.; Nervi, C.; Gobetto, R. Chem. Commun. 2014, 50, 14670-14673.

51. Becke, A. D. J. Chem. Phys. 1993, 98, 5648-5652.

52. Perdew, J. P. Phys. Rev. B 1986, 33, 8822-8824.

53. McLean, A. D.; Chandler, G. S. J. Chem. Phys. 1980, 72, 5639-5648.

54. Krishnan, R.; Binkley, J. S.; Seeger, R.; Pople, J. A. J. Chem. Phys. 1980, 72, 650-654.

55. Frisch, M. J.; Trucks, G. W.; Cheeseman, J. R.; Scalmani, G.; Caricato, M.; Hratchian, H. P.; Li, X.; Barone, V.; Bloino, J.; Zheng, G.; Vreven, T.; Montgomery, J. A.; Petersson, G. A.; Scuseria, G. E.; Schlegel, H. B.; Nakatsuji, H.; Izmaylov, A. F.; Martin, R. L.; Sonnenberg, J. L.; Peralta, J. E.; Heyd, J. J.; Brothers, E.; Ogliaro, F.; Bearpark, M.; Robb, M. A.; Mennucci, B.; Kudin, K. N.; Staroverov, V. N.; Kobayashi, R.; Normand, J.; Rendell, A.; Gomperts, R.; Zakrzewski, V. G.; Hada, M.; Ehara, M.; Toyota, K.; Fukuda, R.; Hasegawa, J.; Ishida, M.; Nakajima, T.; Honda, Y.; Kitao, O.; Nakai, H. Gaussian 09, Gaussian Inc. Wallingford CT 2009.

56. Marenich, A. V.; Cramer, C. J.; Truhlar, D. G. J. Phys. Chem. B 2009, 113, 6378-6396. 